\title{
Cattle Diets on Irrigated Pasture
}

\author{
DAVID A. YATES AND JOE D. WALLACE
}

Highlight: Chemical composition and in vitro organic matter digestibility of grazed forages collected during June, July, and August were compared. Protein in grazed orchardgrass was usually higher than that from alta fescue and forages representing either orchardgrass or fescue were higher in protein than tall wheatgrass forage. During August, protein in grazed forages from all pastures was higher and fiber content lower than during June or July. Lignin content in grazed forage was highest for orchardgrass, intermediate for wheatgrass, and lowest for fescue. Digestibility favored orchardgrass over either fescue or wheatgrass. During the 7-day sampling periods of each month, the quality of diets selected by cattle decreased as sampling period progressed. Suggesions are offered as to when irrigated pasture might be more beneficially used in an integrated system with native range.

Seeded pastures are used to complement native range in livestock operations throughout much of the West. Because of arid conditions in the Southwest, many seeded pastures, e.g., fescue and wheatgrass species, are placed under irrigation to increase their productivity and increase the effectiveness of their use in integrated, yearlong pasture-range systems. Irrigated pastures are used in a variety of ways, e.g., breeding pasture, calving or lambing pasture, spring pasture to delay turnout on native range, pasture for developing replacement stock, and pasture for providing emergency forage during drought periods.

The nutritive value of diets consumed by livestock on native range usually declines with advancing maturity of herbage (Wallace et al. 1972, Havstad et al. 1977); however, on irrigated pasture, an attempt is generally made to provide a continued supply of fairly immature forage through grazing management. The purpose of the present study was to determine the chemical composition and digestibility of diets selected by cattle grazing irrigated grass pastures on a rotational grazing scheme throughout the summer season.

\section{Materials and Methods}

Nine esophageal-fistulated, yearling heifers were used to collect grazed forage samples from irrigated Potomac orchardgrass ( $\mathrm{Dac}$ tylis glomerata), alta fescue (Festuca arundinacea), and Jose tall wheatgrass (Agropyron elongatum) pastures at the New Mexico Agricultural Branch Station near Tucumcari. Grazed samples were collected once daily just after dawn over 7-day periods in June, July and August of 1975 . Three heifers were randomly assigned to each of the three grass species under study.

Each grass species had been seeded as a single stand on 1.8-ha pastures in 1972. The pasture containing each species was sub-

Authors are graduate research assistant and professor, respectively, Department of Animal and Range Sciences, New Mexico State University, Las Cruces, New Mexico 88003

Present address for Mr. Yates is University of Nebraska North Platte Experiment Station, Box 429, North Platte, Nebraska 69101. The authors acknowledge R. F. Beck, K. E. Rosiere and D. H. Williams for their assistance in conducting this research.

The study is Journal Article 650, Agricultural Experiment Station, New Mexico State University, Las Cruces, New Mexico.

Manuscript received October 23, 1977. divided into four equal-sized paddocks which allowed a 7-day on and 21-day off rotational grazing sequence. The pastures were grazed for about 160 days (May to November) during 1973 and 1974 using a stocking rate of five yearling heifers per ha. In 1975, when sampled for the present study, the pastures were stocked at a rate of 6.8 yearling heifers per ha. The pastures were stocked rather lightly to allow ample opportunity for selective grazing of more acceptable plant parts. Average herbage dry matter remaining on the pastures following the three sampling periods in 1975 was $6,118,4,033$ and $1,187 \mathrm{~kg}$ per ha for wheatgrass, fescue, and orchardgrass pastures, respectively.

The pastures were fertilized each year with $225 \mathrm{~kg}$ nitrogen per ha (applied in two equal applications as ammonium nitrate) plus $45 \mathrm{~kg}$ phosphorus per ha as superphosphate. Nitrogen fertilizer was applied in early May along with the single application of phosphorus and the second nitrogen application was made in mid-July.

Esophageal-fistulated heifers were grazed on their respective pastures for 3 weeks prior to the June sampling period and during the full interim between subsequent sampling periods. Grazed samples from the three heifers on each pasture were pooled by day within each 7-day period, thus providing a total of 63 dietary samples over the three sampling periods. Diet samples were collected over a 30- to 40-minute period each day, then thoroughly mixed, subsampled and frozen, and finally dried in a forced-air oven at $50^{\circ} \mathrm{C}$.

The grazed forage samples were ground through a 20-mesh screen in a Wiley mill prior to determination of dry matter, ash, and crude protein according to A.O.A.C. (1970) methods. Acid detergent fiber and lignin were analyzed using Van Soest (1963) procedures, while in vitro organic matter digestibility was determined with the Barnes (1969) revision of the Tillcy and Tcrry (1963) technique.

All data were statistically analyzed by analysis of variance (Steel and Torrie 1960) and when significant $(P<.05) F$-values were found, means were compared using Duncan's new multiple range test (Steel and Torrie 1960).

\section{Results and Discussion}

\section{Protein Content of Grazed Forage}

The protein content of grazed forage from each pasture species during each sampling period is presented in Table 1. Means for each species over the three sampling periods showed that the protein content of forage selected by cattle was highest on orchardgrass $(20.2 \%)$, intermediate on fescue $(17.3 \%)$, and lowest on wheatgrass (13.2\%). Differences among all species were significant $(P<.05)$. Among sampling periods when all species were averaged, the mean protein level for forage selected in August was higher $(P<.05)$ than that selected in either June or July. A species by sampling period interaction was present due to the relatively large $(P<.05)$ differences in protein content of forage grazed on fescue and orchardgrass pastures during July and August while, during June, protein in forages grazed on these two species was essentially the same. Protein values 
Table 1. Mean protein percentage (ash-free) of grazed forage from each pasture during each sampling period'.

\begin{tabular}{|c|c|c|c|c|}
\hline \multirow{2}{*}{$\begin{array}{l}\text { Sampling } \\
\text { Period }\end{array}$} & \multicolumn{3}{|c|}{ Species $^{2}$} & \multirow{2}{*}{$\begin{array}{l}\text { Period } \\
\text { mean }\end{array}$} \\
\hline & Wheatgrass & Fescue & Orchardgrass & \\
\hline & A & B & B & \\
\hline June & $\begin{array}{c}11.7^{\mathrm{a}} \\
\mathrm{A}\end{array}$ & $\begin{array}{c}17.1^{\mathrm{a}} \\
\mathrm{B}\end{array}$ & $\begin{array}{c}17.2^{\mathrm{a}} \\
\mathrm{C}\end{array}$ & $15.3^{n}$ \\
\hline July & $\begin{array}{c}11.8^{\mathrm{a}} \\
\mathrm{A}\end{array}$ & $\begin{array}{c}15.6^{b} \\
\text { B }\end{array}$ & $\begin{array}{c}18.7^{b} \\
C\end{array}$ & $15.3^{\mathrm{a}}$ \\
\hline August & $\begin{array}{c}16.0^{\mathrm{a}} \\
\mathrm{A}\end{array}$ & $\begin{array}{c}19.1^{c} \\
B\end{array}$ & $\begin{array}{c}24.8^{c} \\
C\end{array}$ & $20.0^{b}$ \\
\hline Species mean & 13.2 & 17.3 & 20.2 & \\
\hline
\end{tabular}

'Each value represents the mean of daily samples taken over 7 days.

${ }^{2}$ Means within each column followed by the same small letter are not different $(P<.05)$.

${ }^{3}$ Means within each row under the same capital letter are not different $(P<.05)$.

found in this study are quite similar to those reported by Lake et al. (1974) and Heineman and Russell (1969).

\section{Fiber Content of Grazed Forage}

Forage selected by cattle grazing wheatgrass was higher $(P<.05)$ in fiber than that selected on either fescue or orchardgrass pastures (Table 2). Respective fiber levels (ash-free) in grazed forage averaged over the three sampling periods were $50.3,47.8$, and $46.9 \%$ for wheatgrass, fescue and orchardgrass. Lower $(P<.05)$ fiber levels were observed in forage grazed in August (45.5\%) than either June (49.0\%) or July $(50.5 \%)$. This would suggest that grazing management had been successful in maintaining forages in an immature stage. Fiber levels of forages involved in the present study agree closely with those reported by Lake et al. (1974), but are higher than those observed by Colemand and Barth (1973). Most chemical constituent data reported in the literature are, however, given on a dry matter rather than an ash-free basis.

Table 2. Mean fiber percentage (ash-free) of grazed forage from each pasture during each sampling period'.

\begin{tabular}{|c|c|c|c|c|}
\hline \multirow{2}{*}{$\begin{array}{l}\text { Sampling } \\
\text { period }\end{array}$} & \multicolumn{3}{|c|}{ Species $^{2}$} & \multirow{2}{*}{$\begin{array}{l}\text { Period } \\
\text { mean }\end{array}$} \\
\hline & Wheatgrass & Fescue & Orchardgrass & \\
\hline \multirow{3}{*}{ June } & A & A & $\mathbf{A}$ & \\
\hline & $50.8^{\mathrm{a}}$ & $47.9^{a}$ & $48.3^{a}$ & $49.0^{\mathrm{a}}$ \\
\hline & A & A & A & \\
\hline \multirow[t]{2}{*}{ July } & $51.5^{\mathrm{a}}$ & $51.3^{\mathrm{a}}$ & $48.9^{a}$ & $50.5^{\mathrm{a}}$ \\
\hline & A & B & B & \\
\hline \multirow[t]{2}{*}{ August } & $48.6^{a}$ & $44.4^{b}$ & $43.6^{b}$ & $45.5^{b}$ \\
\hline & A & B & B & \\
\hline Species mean & 50.3 & 47.8 & 46.9 & \\
\hline
\end{tabular}

1Each value represents the mean of daily samples taken over 7 days.

2Means within each column followed by the same small letter are not different $(P<.05)$.

${ }^{3}$ Means within each row under the same capital letter are not different $(P<.05)$.

\section{Lignin Content of Grazed Forage}

The lignin content of grazed forage was generally highest for orchardgrass, intermediate for wheatgrass, and lowest for fescue (Table 3); however, an interaction $(P<.05)$ occurred between sampling period and species. During June, the lignin content in grazed-wheatgrass forage was similar to that grazed on the fescue pasture $(6.1$ vs $5.6 \%)$ but during the remaining periods grazed-wheatgrass was higher $(P<.05)$ than that from the fescue pasture. When averaged over the three sampling periods, the lignin content of grazed forage from the wheatgrass, fescue, and orchardgrass pastures was $6.8,5.8$, and $9.0 \%$, respectively. Mean lignin values for the different sampling periods (averaged over all grass species) were essentially the same (Table 3).
Table 3. Mean lignin percentage (ash-free) of grazed forage from each pasture during each sampling period.

\begin{tabular}{|c|c|c|c|c|}
\hline \multirow{2}{*}{$\begin{array}{l}\text { Sampling } \\
\text { period }\end{array}$} & \multicolumn{3}{|c|}{ Species $^{2}$} & \multirow{2}{*}{$\begin{array}{c}\text { Period } \\
\text { mean }\end{array}$} \\
\hline & Wheatgrass & Fescue & Orchardgrass & \\
\hline \multirow{3}{*}{ June } & A & A & B & \\
\hline & $6.1^{\mathrm{a}}$ & $5.6^{\mathrm{a}}$ & $9.7^{\mathrm{a}}$ & $7.1^{\mathrm{a}}$ \\
\hline & A & B & $\mathrm{C}$ & \\
\hline \multirow{2}{*}{ July } & $7.4^{b}$ & $5.9^{\mathrm{a}}$ & $9.2^{\mathrm{a}}$ & $7.5^{\mathrm{a}}$ \\
\hline & A & B & $\mathrm{C}$ & \\
\hline \multirow[t]{2}{*}{ August } & $6.9^{b}$ & $5.9^{\mathrm{a}}$ & $8.2^{b}$ & $7.0^{\mathrm{a}}$ \\
\hline & A & B & $\mathrm{C}$ & \\
\hline Species mean & 6.8 & 5.8 & 9.0 & \\
\hline
\end{tabular}

Each value represents the mean of daily samples taken over 7 days.

${ }^{2}$ Means within each column followed by the same small letter are not different $(P<.05)$.

${ }^{3}$ Means within each row under the same capital letter are not different $(P<.05)$.

\section{Organic Matter Digestibility of Grazed Forage}

In vitro organic matter digestibility data (Table 4$)$ revealed a species by sampling period interaction $(P<.05)$ indicating that digestibility values among species*were somewhat inconsistent across sampling periods. The digestibility of orchardgrass was higher $(P<.05)$ than other species in July, but was the same as wheatgrass in June and did not differ $(P<.05)$ from fescue in August. The digestibility of forage grazed by cattle averaged across all sampling periods was highest on orchardgrass $(71.3 \%)$ and practically the same for fescue (68.0\%) and wheatgrass (68.3\%). Digestibility was highest in August for all species except wheatgrass, which was slightly higher in June.

Table 4. Mean organic matter digestibility (in vitro) of grazed forage from each pasture during each sampling period'.

\begin{tabular}{|c|c|c|c|c|}
\hline \multirow{2}{*}{$\begin{array}{l}\text { Samplings } \\
\text { period }\end{array}$} & \multicolumn{3}{|c|}{ Species $^{2}$} & \multirow{2}{*}{$\begin{array}{c}\text { Period } \\
\text { mean }\end{array}$} \\
\hline & Wheatgrass & Fescue & Orchardgrass & \\
\hline & A & B & A & \\
\hline June & $70^{\mathrm{a}}$ & $66^{a}$ & $70^{a}$ & $68.7^{a}$ \\
\hline July & $\begin{array}{c}A \\
66^{b} \\
A\end{array}$ & $\begin{array}{c}A \\
66^{\mathrm{a}} \\
\mathrm{B}\end{array}$ & $\begin{array}{c}\text { B } \\
70^{2} \\
\text { B }\end{array}$ & $67.3^{2}$ \\
\hline August & $69^{a}$ & $72^{b}$ & $74^{b}$ & $71.7^{\mathrm{b}}$ \\
\hline Species mean & $\begin{array}{c}A \\
68.3\end{array}$ & $\begin{array}{c}A \\
68.0\end{array}$ & $\begin{array}{c}\text { B } \\
71.3\end{array}$ & \\
\hline
\end{tabular}

'Each value represents the mean daily samples taken over 7 days.

${ }^{2}$ Means within each column followed by the same small letter are not different $(P<.05)$

${ }^{3}$ Means within each row under the same capital letter are not different $(P<.05)$.

The high digestibility of orchardgrass forage along with its high lignin (Table 3 ) and high protein (Table 1) may indicte that either some of the lignin was artifact or that the ligno-cellulose bonds of orchardgrass were easily broken and did not affect digestibility. Higher lignin values are generally associated with a depression in digestibility (Colburn et al. 1968).

Results of this study show that nutritive value of these species is likely to be somewhat higher in the early and later part of the summer than during mid-summer. Consequently, management systems where such species are integrated with native range might benefit from avoiding use of the irrigated pasture during mid-summer when their requirement for irrigation water is also highest.

\section{Composition and Digestibility by Day of Sampling Period}

Chemical composition and in vitro organic matter digestibility for grazed forages collected on individual days (within 7-day periods) averaged across all species and all sampling periods are shown in Table 5 . Trends indicate that cattle 
Table 5. Mean chemical composition and organic matter digestibility (in vitro) of grazed forage by day within sampling period for all species and all periods. 1

\begin{tabular}{ccccc}
\hline \multirow{2}{*}{$\begin{array}{c}\text { Day of } \\
\text { sampling } \\
\text { period }\end{array}$} & \multicolumn{4}{c}{ Component Means $^{2}$} \\
\cline { 2 - 5 } & Protein & Fiber & Lignin & O.M. Digestibility \\
\hline & $25.6^{\mathrm{a}}$ & $39.7^{\mathrm{a}}$ & $6.8^{\mathrm{a}}$ & $78^{\mathrm{a}}$ \\
1 & $18.2^{\mathrm{b}}$ & $47.2^{\mathrm{b}}$ & $7.1^{\mathrm{a}}$ & $71^{\mathrm{b}}$ \\
2 & $17.1^{\mathrm{bc}}$ & $49.1^{\mathrm{bc}}$ & $7.2^{\mathrm{a}}$ & $70^{\mathrm{bc}}$ \\
3 & $15.3^{\mathrm{cd}}$ & $50.6^{\mathrm{cd}}$ & $7.4^{\mathrm{a}}$ & $68^{\mathrm{cd}}$ \\
4 & $15.0^{\mathrm{d}}$ & $49.4^{\mathrm{bcd}}$ & $7.1^{\mathrm{a}}$ & $67^{\mathrm{cd}}$ \\
5 & $13.7^{\mathrm{d}}$ & $50.4^{\mathrm{dd}}$ & $7.5^{\mathrm{a}}$ & $66^{\mathrm{de}}$ \\
6 & $13.4^{\mathrm{d}}$ & $52.0^{\mathrm{d}}$ & $7.4^{\mathrm{a}}$ & $64^{\mathrm{e}}$ \\
7 & &
\end{tabular}

${ }^{1}$ Each value represents the mean for all species across all sampling periods. Chemical components are given on an ash-free basis.

${ }^{2}$ Means within each column followed by the same letter are not different $(P<.05)$.

selected higher quality diets (higher in protein and digestibility and lower in fiber) early in the 7-day sampling periods. As sampling periods progressed, protein and digestibility decreased while fiber increased, although many day-to-day differences were not significant $(P<.05)$.

Day means for lignin content in grazed forage appeared to increase slightly through day four and level off thereafter. In contrast to other components studied, none of the differences in lignin content were significant $(P<.05)$.

Greatest differences between consecutive days for all components studied occurred between days one and two (Table 5). This may have been caused by the strong preference observed for isolated alfalfa plants present in each pasture on day one of each sampling period. Hand separation of clipped samples taken prior to grazing indicated that alfalfa made up less than $1 \%$ of the total available herbage in each pasture; moreover, alfalfa plants were extremely difficult to locate within all pastures following the initial sampling day.

Among chemical components studied, protein showed the greatest change from day one through day seven, with respective percentages declining from 25.6 to 13.4. Changes in organic matter digestibility wre also noteworthy, with the day one value of $78 \%$ compared to the day seven value of $64 \%$.

\section{Literature Cited}

A.O.A.C. 1970. Official Methods of Analysis (11th ed.). Association of Official Agricultural Chemists. Washington, D.C.

Barnes, R. F. 1969. Collaborative research with the two-stage in vitro technique (paper N). Proc. Nat. Conf. on Forage Eval. and Util., Lincoln, Nebr.

Coleman, S. W., and K. M. Barth. 1973. Quality of diets selected by grazing animals and its relation to quality of available forage and species composition of pastures. J. Anim. Sci. 36-754:761.

Colburn, M. W., J. L. Evans, and C. H. Ramage. 1968. Apparent and true digestibility of forage nutrients by ruminant animals. J. Dairy Sci. 51:1450-1457.

Havstad, K., R. D. Pieper, G. B. Donart, and J. D. Wallace. 1977. Cattle diets and herbage on fertilized and unfertilized blue grama rangeland. Proc. Wes. Sec. Amer. Soc. Anim. Sci. 28:112-115.

Heinemann, W. W., and T.S. Russell. 1969. Evaluation of rotation-grazed pastures from esophageal and hand-gathered samples. Agron. J. 61: 547-550.

Lake, R. P., D. C. Clanton, and J. E. Karn. 1974. Intake, digestibility, and nitrogen utilization of steers consuming irrigated pasture as influenced by limited energy supplementation. J. Anim. Sci. 38:1291-1297.

Steel, R. G. D., and J. H. Torrie. 1960. Principles and Procedures of Statistics. McGraw-Hill Book Co., New York.

Tilley, J. M. A., and R. A. Terry. 1963. A two-stage technique for the in vitro digestion of forage crops. J. Brit. Grassl. Soc. 18:104-111.

Van Soest, P. J. 1963. Use of detergents in the analysis of fibrous feeds. II. A rapid method for the determination of fiber and lignin. J. Ass. Official Agr. Chem. 46:829-835.

Wallace, J. D., J. C. Free, and A. H. Denham. 1972. Seasonal changes in herbage and cattle diets on sandhill grassland. J. Range Manage. 25:100-104.

\title{
rangeland reference areas
}

by

\author{
William Laycock, Chairman \\ SRM Rangeland Reference Area Committee
}

This third publication in the Range Science Series reviews the published literature dealing with rangeland reference areas, summarizes current programs of other groups in the United States and Canada who are interested in natural area preservation, lists activities in other countries, and outlines a program useful for encouraging preservation of reference areas. Rangeland Reference Areas is of particular value to those interested in range research as well as preservation of reference areas and would be an excellent supplementary text for range students at the college level.

- soft cover $\bullet 72$ pages $\bullet$ illustrated $\bullet$ bibliography $\bullet \$ 1.50$ postpaid 